\title{
ROLE OF PURINERGIC RECEPTORS IN THE ACTIVATION OF HUMAN AIRWAY SMOOTH MUSCLE CELLS BY THE ANTIMICROBIAL PEPTIDE LL-37
}

\section{Suzanne Zuyderduyn, Dennis K. Ninaber, Pieter S. Hiemstra and Klaus F. Rabe}

Dept of Pulmonology, C3-P, Leiden University Medical Center, Leiden, The Netherlands

WINNING ABSTRACT: Inflammatory cells that infiltrate and surround the airway smooth muscle (ASM) layer express antimicrobial peptides including the cathelicidin LL-37. LL-37 has been shown to activate epithelial cells by transactivation of the epidermal growth factor receptor (EGFR). Previously, we have shown that LL-37-induced IL-8 release by ASM cells was not dependent on either formyl peptide receptors or the EGFR (ATS 2005). In monocytes LL-37 induces processing of IL-1 $\beta$ through activation of the purinergic $\mathrm{P}_{2} \mathrm{X}_{7}$ receptor. Therefore, the aim of our study was to evaluate the role of purinergic receptors in LL37-induced activation of ASM cells, and to explore the involvement of several intracellular signalling pathways.

ASM cells were cultured and serum-deprived 24 hours before stimulation with LL-37 $\left(10 \mu \mathrm{g} \cdot \mathrm{ml}^{-1}\right)$. The purinergic receptor antagonist suramin and inhibitors of ERK1/2, p38, Src and PI3K were preincubated for one hour. ERK1/2 phosphorylation was assessed by Western Blot, and IL-8 release was determined in supernatants using a sandwich ELISA. RT-PCR was performed for $\mathrm{P}_{2} \mathrm{X}_{7}$ on untreated ASM cells. LL-37 induced ERK1/2 phosphorylation and IL-8 release; both were inhibited by suramin (IL-8: 86\%). Inhibitors of ERK1/2, p38 and Src signalling also reduced LL-37-induced IL-8 release (by $67 \%$, $63 \%$ and $76 \%$, respectively), suggesting a role for these pathways. $\mathrm{P}_{2} \mathrm{X}_{7}$ mRNA was expressed in ASM cells.

These data show that LL-37-induced IL-8 release is mediated via purinergic receptors, ERK1/2 activation, p38 and Src signalling. Our PCR data are in line with the hypothesis that also in ASM P2X $\mathbf{X}_{7}$ is the purinergic receptor involved in LL-37 signalling, although this needs further investigation.

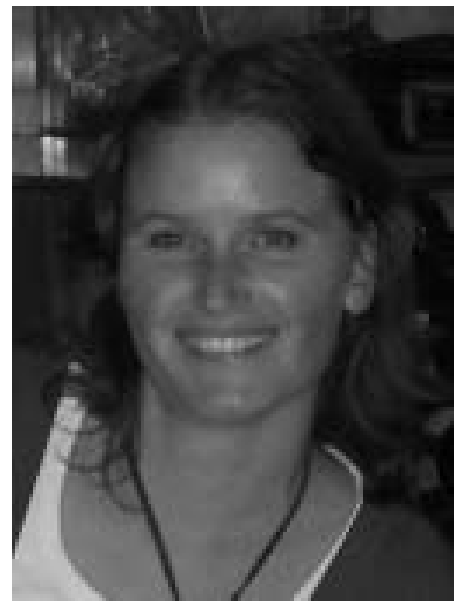

Suzanne Zuyderduyn

Dept of Pulmonology, Leiden University Medical Center, Leiden, The Netherlands

\section{MY JOB AND THE UNIT IN WHICH I WORK}

I was trained as a biomedical scientist at Leiden University (Leiden, the Netherlands) and work at the Dept of Pulmonology at the Leiden University Medical Center (LUMC). In this article, I would like to give you some information on how I was trained to become a biomedical researcher, on the department I work in and on my research itself.

In Leiden, the LUMC (a collaboration between the Medical Faculty and the University Hospital) offers two separate curricula: the Medical School and Biomedical Sciences. The latter was designed to train researchers and is composed of a 3yr Bachelor programme and a 2-yr Masters programme. The first year of the Bachelor programme focuses on molecular and cellular sciences, whereas in the second year, more basic biomedical courses, such as immunology and pathology, are on the programme. In the third year of study, the knowledge gained in the first $2 \mathrm{yrs}$ is integrated and students can choose courses within and outside the LUMC. During a 3-month training period, students are introduced to research by doing a small research project in a laboratory of their choice.

The research specialisation of the international Masters programme (all courses are given in English) aims to deepen and broaden the student's knowledge within the research areas in the LUMC. The students do two junior research projects in two different laboratories, write a research proposal before starting their second junior research project, and follow "Frontiers of Science" courses, which focus on the latest research performed in several departments of the LUMC. Throughout the Bachelor and Masters programmes, the students are trained in presenting their results, and writing research proposals and articles to prepare them for their new careers.

During my studies, I had three training periods. In these training periods I performed research at the Dept of Infectious Diseases of the LUMC, the Dept of Human Genetics of the LUMC and the Dept of Immunology and Infectious Diseases at TNO Prevention and Health in Leiden. During these periods I found that I enjoyed doing research and therefore I decided to start as a PhD student at the Dept of Pulmonology at the LUMC. My thesis will contain several articles published in international peer-reviewed journals and I hope to defend my thesis in 2007.

Our department is composed of a clinical part for patient care (ward, outpatient clinic and bronchoscopy unit), the lung function laboratory and the Laboratory for Respiratory Cell 
Biology and Immunology. My work is performed in the Laboratory for Respiratory Cell Biology and Immunology, but due to the close proximity of our clinical ward and lung function laboratory, many interactions take place between the researchers, clinicians and nurses working within these three different parts of the department. During our weekly scientific discussion clinicians, scientists and technicians meet to discuss their work.

\section{MY RESEARCH AS PART OF MY WORKING GROUP/ RESEARCH TEAM}

In the Laboratory for Respiratory Cell Biology and Immunology, the research lines of the department are: asthma, chronic obstructive pulmonary disease (COPD) and lung cancer (see [1] for details). Basic and clinical research is focused on the role of epithelial cells, airway smooth muscle cells and CD8+ T-cells in asthma and COPD. The research group has a special interest in antimicrobial peptides, proteinase inhibitors and innate immunity in the lung, as well as in growth factors and their receptors. Recent studies also focus on innate immunity in lung cancer. Other activities in the laboratory include diagnostic assays for $\alpha_{1}$-antitrypsin deficiency, allergy and monitoring of pollen concentrations. In the laboratory cell cultures, as well as bronchial biopsies, sputum and exhaled breath condensate are studied and therefore basic and clinical science are integrated. As outlined later, my specific research project focuses on the role of human airway smooth muscle cells (HASM) in the pathogenesis of asthma. Also in this project, both cell culture as well as tissue analysis are central.

\section{MY WINNING POSTER AS PART OF MY RESEARCH}

HASM cells are the cells responsible for contraction of the airways. In asthma, these cells respond in an exaggerated manner to stimuli that do not provoke such an effect in healthy people. In addition to their role in contraction, HASM cells are also involved in remodelling of the airways and in airway inflammation.

Our research has mainly focused on the latter role of HASM cells. In our laboratory we isolate and culture HASM cells from resected lung tissue and culture cells from commercial sources, and subject these cells to stimuli we think are important in asthma and COPD, including T-helper cell (Th)2 cytokines and antimicrobial peptides. Our studies have shown that the Th2 cytokines interleukin (IL)-4 and -13 induce release of the eosinophil-attracting chemokines eotaxin and eotaxin-3 by HASM cells [2]. In addition, we have found that the profibrotic cytokine transforming growth factor (TGF)- $\beta$ differentially regulates Th2 cytokine-induced chemokine release: eotaxin release was slightly enhanced, whereas eotaxin-3 release was inhibited. TGF- $\beta$ may dampen the inflammatory response by reducing eotaxin-3 release, thereby resolving chronic eosinophilia.

A more recent study in our laboratory has focused on the effect of the antimicrobial peptides on chemokine release by HASM cells. We have found that the human cathelicidin peptide LL37 enhances IL-8 release from HASM cells, whereas the human neutrophil defensins (HNP1-3) do not [3]. LL-37-induced activation of HASM cells does not involve transactivation of the epidermal growth factor receptor, as has been shown for epithelial cells [4], nor does it involve formyl peptide receptors, which are important for the LL-37-induced chemotaxis of neutrophils and eosinophils [5]. Figure 1 shows the receptors used by LL-37 to activate various cell types. We have now extended our findings and have shown that the purinergic $\mathrm{P} 2 \mathrm{X}_{7}$ receptor is likely to be the receptor activated by LL-37 on HASM cells (see abstract ERS 2006). By inducing IL-8 release by HASM cells, LL-37 may enhance recruitment of inflammatory cells to the airways. a)

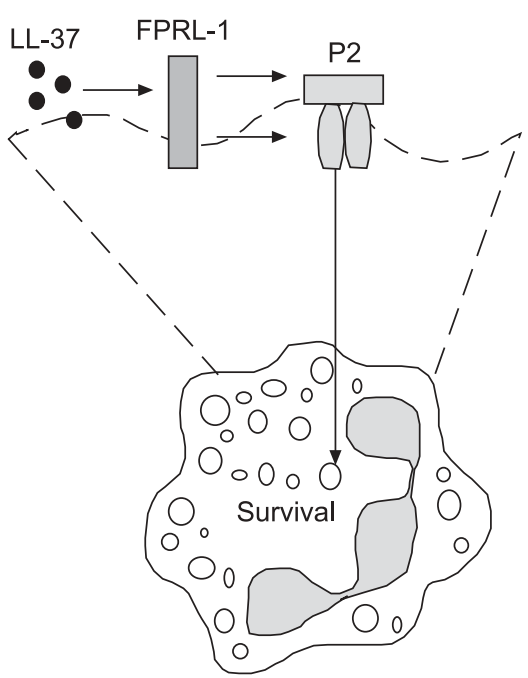

b)

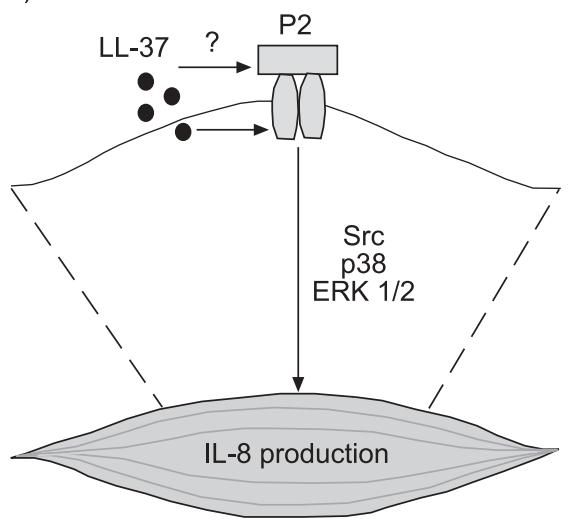

c)

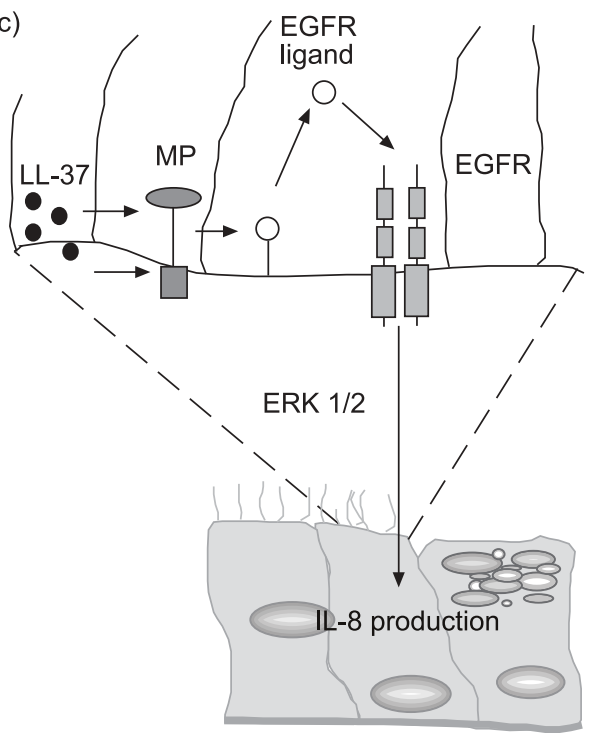

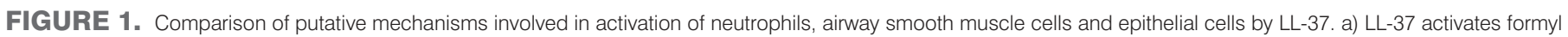

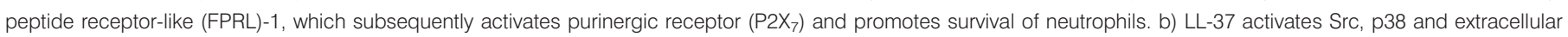

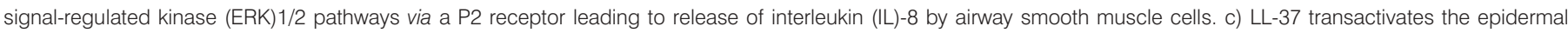

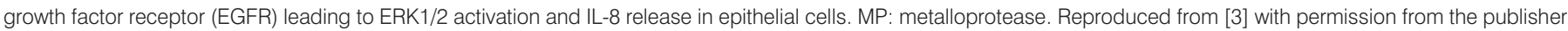




\section{THE IMPACT OF MY WORK ON CLINICAL OR RESEARCH} PRACTICE

These studies help to better understand the mechanism by which antimicrobial peptides, such as LL-37, activate inflammatory cells and resident cells to combat infection. Future studies will focus more on the role of cholinergic receptors on HASM cells and epithelial cells in COPD.

\section{REFERENCES}

1 Leids Universitair Medisch Centrum. www.lumc.nl/1070. Date last updated: January 11, 2007. Date last accessed: April 3, 2007.

2 Zuyderduyn S, Hiemstra PS, Rabe KF. TGF-beta differentially regulates $\mathrm{TH} 2$ cytokine-induced eotaxin and eotaxin-3 release by human airway smooth muscle cells. J Allergy Clin Immunol 2004; 114: 791-798.

3 Zuyderduyn S, Ninaber DK, Hiemstra PS, Rabe KF. The antimicrobial peptide LL-37 enhances IL-8 release by human airway smooth muscle cells. J Allergy Clin Immunol 2006; 117: 1328-1335.

4 Tjabringa GS, Aarbiou J, Ninaber DK, et al. The antimicrobial peptide LL-37 activates innate immunity at the airway epithelial surface by transactivation of the epidermal growth factor receptor. J Immunol 2003; 171: 6690-6696.

5 Tjabringa GS, Ninaber DK, Drijfhout JW, Rabe KF, Hiemstra PS. Human cathelicidin LL-37 is a chemoattractant for eosinophils and neutrophils that acts via formyl-peptide receptors. Int Arch Allergy Immunol 2006; 140: 103-112. 